\title{
Institutional Influence in Pakistan: Bureaucracy, Cabinet and Parliament
}

\author{
Mahboob Hussain ${ }^{1} \&$ Rizwan Ullah Kokab ${ }^{2}$ \\ ${ }^{1}$ Department of History \& Pakistan Studies, University of the Punjab, Lahore, Pakistan \\ ${ }^{2}$ Department of History, Government College, University, Faisalabad, Pakistan \\ Correspondence: Mahboob Hussain, Department of History \& Pakistan Studies, University of the Punjab, \\ Lahore, Pakistan. E-mail: profmahboob@yahoo.com
}

Received: March 17, $2013 \quad$ Accepted: April 16, $2013 \quad$ Online Published: June 1, 2013
doi:10.5539/ass.v9n7p173

\begin{abstract}
This paper discusses the mutual relationship of some important institutions of the state of Pakistan; the institutions of bureaucracy, cabinet, chief executive and the parliament. It observes the domination of the one over the other. The discussion covers the period from 1947 to 1977 . The analysis highlights the strong domination of Chief Executive over the bureaucracy and cabinet. The paper then examines the power and influence of the parliament which were weaker than those of bureaucracy and cabinet. The findings have been made through the analysis of the events, the quotations from some reliable research works, statements of various key leaders and debates in the Assemblies.
\end{abstract}

Keywords: institution, parliament, cabinet, executive, constitution, domination

\section{Introduction}

Pakistan has never been a country where the institutions had been stronger than personalities. The country has generally done well under authoritarian rule though much depends on the way in which that authority is exercised. (British Ambassador to Islamabad, 1973)

In Pakistan Parliament is mostly a subordinate legislature. Here, the executive is without exception, a pre-eminent player on the national scene. It initiates decisions in party forums, which are translated into law through the legislative procedure, and are then rigidly defined, implemented and controlled by the Bureaucracy. Given the domination of extra-Parliamentary forces over the power structure of Pakistan, Parliamentary institutions are often considered by political players as necessary accoutrements of a modern ruling structure. In other words, these institutions legitimize the existing political order. Even if real power resides outside the legislature, the power holders need to win legal and moral authority. Not surprisingly, each of the four military governments tried to fill the gap of legitimacy by creating assemblies through holding elections. (Waseem, 2006: 32)

\section{Civil Bureaucracy's Influence}

In Pakistan, the vital role of bureaucracy in running the system of government cannot be denied at all. In contrast to the democratic institution of Parliament the bureaucratic influence remained the key government institution and parliament remained marginalized most of the time. The bureaucracy had been the senior partner in the military- bureaucratic oligarchy that ruled Pakistan since its inception. It was powerful enough to keep the military at bay even during the Martial Law regimes. (Alavi, 1988: 242)

The power equation between the executive and the legislative during the early days of the country's independence was inherited from the British. The Colonial Power controlled India through strengthening the state Bureaucracy. This pattern persisted in the ensuing years, and the civil military Bureaucracy developed an interest in controlling the state and its politics. (Siddiqa, 2007: 67-68)

The bureaucracy is trained to protect the state from external as well as internal threats. According to Alavi, 'the bureaucrats were brought up on the myth of "guardianship," the idea that it was their mission to defend the interests of the people as against the supposed partnership of and personal ambitions of "professional" politicians.' (Siddiqa, 2007: 68) 
It was not only the civil bureaucracy that was the stronger element in making and enforcing the decisions but the bureaucracy had close links with the institution of Army and both the institutions had close relationship in ruling over the country. Sometime one institution had been stronger to dictate the other one and at some time other institution became stronger to control the former one. However the ultimate arbiter role can only be played by the stronger civil-military bureaucracy and not by democratic institutions. (Siddiqa, 2007: 68)

Until Liaquat Ali's demise in 1951 civil servants were closely attached with the power. Both Jinnah and Liaquat relied heavily on the bureaucrats and Jinnah encouraged the top bureaucrats of various departments at the centre and the provincial chief secretaries to communicate with him directly on matters of vital interests. (Hamid, 1993: 71; Islam, 1987: 12; Sayeed, 1958: 131; Kaushik, 1985: 41)

Three of the four Governors under Quaid-i-Azam Jinnah were British and former Indian Civil Service (ICS) officers and two of these Governors presided over cabinet meetings. One of them was even able to reallocate the portfolios without the approval of his Chief Minister. All of them wrote fortnightly letters to the Governor-General Jinnah giving detailed account of everything ranging from intrigues in the provincial cabinets to details of refugee rehabilitation of the food problem. Jinnah also used to call the secretaries over the heads of the ministers. After his death, Liaquat Ali Khan whose authority was never as great as that of the Quaid-i-Azam, continued to receive reports from the Chief Secretaries of the provinces. (CAP Debate, 1955; Bhuiyan, 1982: 52)

Yet the analysts agree that civil servants found it virtually impossible to dominate the political system due to the leadership of Jinnah and Liaquat Ali. (Chowdhury, 1988: 100) After Liaquat Ali's death, leading role of the politicians ended and the period of the ascendant bureaucracy began, which continued until October 1958 when the military seized control from its partner in complicity. (Mazari, 2001: 56)

Some scholars consider that the civil bureaucracy continued to wield power after the introduction of martial law in 1958. So great was the dependence of Ayoob government on its cooperation that it was armed with greater powers and shielded from public criticism. (Ahmad, 1959: 229) Therefore it is assumed that the bureaucracy continued its rule which had been gathered during 1951-1958 when the chief executives were members of bureaucracy during the martial law regime through a new legitimizing agent, on the place of political leadership, the Armed Forces. (Ayub, 1972: 21) After the promulgation of martial law, within a few years the President Ayub became a 'prisoner' of the bureaucracy because the civil servants regained their position at the end of 1959, and henceforth bureaucracy played a dominant role in policy-making during the Ayub regime. (Chowdhury, 1988: 104)

Rizwan Ullah Kokab (2010: 110-112) has negated the influence of the bureaucracy over the state in contrast to the influence of the Chief Executive - a single man or dictator. It has been contended that the Chief Executive needed a system to represent his authority over the common people. He, fortunately for him, had a governmental structure lent itself to control by an elite group of administrators or by one man. The centralized exercise of power by the secretariat could also help the few people to control over whole machinery of civil service. There was a hierarchy of decision-making personnel from the district officer to the President/Governor General. Even, despite Pakistan being a federation constitutionally, the provincial governments were under the firm control of the central government because of the latter's emergency powers, its control over personnel, its greater financial resources and the institutional habits and precedents that constituted Pakistan's inheritance from the days of British rule. Therefore the Central and provincial secretaries, who were, in a very real sense, the administrative communication centres and played a dominant role in the governing of Pakistan, (Goodnow, 1964: 140-141) were lured by or used by the President. However, the influence of the bureaucracy in contrast to the parliament has neither been negated by Kokab (2010) nor by any other scholar. It is often contended that the bureaucracy had been stronger than the institution of parliament before Bhutto.

Z. A. Bhutto enjoying populist support tried to control the bureaucrats through 'purges' or structural changes. Through the 1973 administrative reforms, Bhutto sought to establish civilian supremacy over Bureaucracy. His goal was that at the macro level, the Bureaucracy should accept the supremacy of the political leadership and, as Sofia Mumtaz opined, representative institutions. (Shafqat, 2002: 215)

In his endeavour to cow down the Bureaucracy Bhutto abolished the special guarantees for the civil service of Pakistan which were previously ensured in the first two constitutions. (Porte, 1976: 117)

In the aftermath of the 1971 war the former government was characterized in the press as 'corrupt, 'weak', and 'inefficient'. In this context less than 3 months after Bhutto became President of Pakistan, he promulgated the Removal from Service (Special Provisions) Regulation, 1972 under Martial Law No. 14. Press reports of the period list a total of 1828 officers who were compulsorily retired as consequence of the regulation - six times as many as were removed in 1969. This development weakened the power of each cadre of services to some extent, 
but it weakened the influence of the CSP to a relatively greater extent. Consequently the Bureaucracy, and particularly the CSP, became less able to block change and less able to resist political control. (Kennedy, 1987, p. 80)

Despite the effort of Bhutto to control the Bureaucracy, the bureaucratic hold on the state essentially remained strong. Ultimately the weakness of bureaucracy in the early period of Bhutto Government, in the later part of the period Bhutto's kangaroo bureaucracy became stronger and it became a key factor in Bhutto's system of governance. The remoulded bureaucracy was now used to enforce an authoritarian order notably in the shape of police repression. (Yusuf, 1980: 131, 139) Power was in the hands of those bureaucrats whom Bhutto trusted, and he made most decisions himself. (Brief, 1976)

The rule of bureaucratic machinery was so overwhelming that even the ministers had to issue the statements that the government was being run by the bureaucracy and such statements were resounded in the parliament. On $27^{\text {th }}$ February 1976, a member of National Assembly sought leave to move an adjournment motion to discuss the statement of the Federal Minister for Communications published in the daily Jang dated the $23^{\text {rd }}$ December 1975 , alleging that the Government was not being run as the People's Government but as a Government under the Bureaucracy. Though the Chairman ruled the motion out of order on the ground that it did not relate to a matter of recent occurrence (Senate Debates, 1976, February 27) yet the incident can be marked a sign of the control of bureaucratic machinery of the government in contrast to the parliament.

The parliament seldom could assert its full control over the tactful bureaucracy that was in fact controlled by the strong chief executive. Most of the time, the parliament could just pass or reject the resolutions or the motions in contrary to the executive that could manage the actions without the consent of the parliament.

Misbehaving of police or bureaucratic officials to the Parliamentarians became the subject of discussion in Parliament on a number of occasions. One such issue was raised in National Assembly on $17^{\text {th }}$ December 1974 when Speaker of National Assembly took up the pending privilege motion of Sher Baz Khan Mazari. It was alleged in the motion that police officials did not allow him to see the detainees at Sihala prison and, as such, violated the privilege of a member of the National Assembly. On the explanation of Minister of State for Parliamentary Affairs that there was no violation of the privilege, which needed intervention by the Assembly the mover pointed out that members were the representatives of the people and should not have been humiliated by public functionaries. It was also urged that the dignity of members should be recognized, irrespective of their affiliation to treasury benches or otherwise. The minister, agreeing with honorable members held out an assurance that Government would look into the grievances of the honorable member and, if necessary, the defaulting officials would be admonished. He also assured that he would report to the House as to what had been done. Speaker thereupon observed the members of the National Assembly must be respected as such whether they are on that side or this side of the House. (NAD, 1974)

In spite of appearing such motions in the Parliament the Bureaucracy did not have the influence of the Parliament. In the start of his government Bhutto cowed down the Bureaucracy it was not through or by the Parliament. In the later part of his government Bureaucracy was cooperating the Chief Executive the Parliament was not the commanding institution vis-a-vis the Bureaucracy.

In contrast to the institution of parliament the institution of bureaucracy was stronger to hold the control over the government in Pakistan. While in contrast of the institution of the bureaucracy the institution of the Chief Executive remained powerful until the end of Bhutto government in 1977. The bureaucracy was used as a machinery to continue the government of the personalities who dominated the government in any way.

\section{Cabinet and Parliament}

In the parliamentary system the cabinet is a group of ministers that is selected from the parliament. The ministers of the cabinet govern the country. The most relevant precedent of the rule of cabinet can be put from the British parliamentary system when the cabinet is collectively responsible as a decision making body extracted from the main institution of parliament.

In Pakistan before the assassination of Liaquat Ali Khan the cabinet remained insignificant in the face of the Chief Executive except on the occasions when the Chief Executive of the state was to be nominated by the cabinet. It was the cabinet that nominated

Khwaja Nazimuddin as Governor-General after the death of Quaid-i-Azam. Again the cabinet nominated Ghulam Muahmmad as Governor-General and Khwaja Nazimuddin as Prime Minister when Liaquat Ali Khan was assassinated. Despite this decisive dominating role of the cabinet in running the affairs of the state the Chief Executive of the country remained indomitable in the face of the cabinet throughout the period of controlled 
democracy from 1952 to 1958 .

In most of the cases the Chief Executive - Prime Minister, President or Governor General as the case was would be the main actor or influential than the institution of Cabinet. For instance Yunus Samad has observed the supremacy of the planning committee composed of secretaries from all the ministries over the Cabinet from 1947 to 1953 that in reality the committee was a parallel Cabinet composed of and headed by bureaucrats. All important decisions were first reached there and then presented to the Cabinet for token approval. (Alavi, 1988: 127)

Throughout the government of Ayub Khan from 1958 to 1969 President Ayub ran the government free from any fetters on his authority on behalf of any other institution. His government was highly centralized both for the purposes of law-making and policy decisions. (Ahmad, 1959: 179) Ayub Khan in his person and very few of his close aidees like Manzoor Qadir, would lead the decisions of the Cabinet also. Despite the presence of the able personalities in it the Cabinet itself was the group of persons who were in fact near and dear to Ayub Khan. Therefore the Cabinet could not be seen working as a powerful institution.

Then Yahya regime carried on the same pattern of domination of the Chief Executive over the institution of the cabinet. Thus before the Bhutto regime, the Cabinet had not been a substantial institution vis a vis the Chief Executive or Parliament.

As far as abilities of the ministers were concerned Bhutto's first team of ministers was unique in several ways. Barring Tridev Roy and Nurul Amin all the others were members of his political party. Almost all of them had gone to university. Five of them had attended institutions of higher learning abroad. Seven out of ten ministers were practicing lawyers and one a practicing consulting civil engineer. One was a retired judge of a high court. Except Jatoi, none of them were big landlords. It was a Cabinet of professional men from the middle class and it was to serve Bhutto well during the first year of his government. The team went to work with zeal and dedication. It was truly a dedicated team. (Hasan, 2000: 17)

In spite of the capabilities and abilities to run the affairs of state the cabinet could not assert in the face of the powers and influence of the popular, dominating and powerful Chief Executive, Z. A. Bhutto. The decisions of the cabinet were mainly the reflections of the thoughts, ideas and ponderings of Bhutto and the cabinet often endorsed, explained or clarified the thoughts of Bhutto. The differences with Bhutto were nominal or when they were stronger they resulted into the change of the ministers.

The latter cabinet of Bhutto was weaker than the former cabinet as this team was less parliamentary as well as incapable and less democratic than the former one. Hussain Haqqani views that Bhutto's original political team had been replaced by a new team of ministers and advisers from the civil and military establishment. Under the influence of this team, the PPP's secretary general perceived "Bhutto's tilt toward an-d obscurantist interpretation of Islam. (Haqqani: 106) This team was again the Cabinet of the Chief Executive and decided more with the consent of the Chief Executive.

The cabinet was influence by the Chief Executive. The Parliament, however, was not free from the influence of the Cabinet. Not only invisible influence of the Cabinet, rather of the Prime Minister through the Cabinet, the Speaker of the National Assembly who was the custodian of one of the houses of the Parliament at one occasion did not hesitate to attend the meeting of the Cabinet of which in fact he was not the part. This was critically pointed out in the National Assembly on $24^{\text {th }}$ June 1974 by Sahibzada Ahmad Raza Khan Qasuri. He drew attention of the House to a photograph of a Cabinet meeting with the Speaker sitting next to the Prime Minister, as published in a newspaper and observed that Speaker was not a member of the Cabinet and he had no place in a party meeting or the meeting of the executive and was rather above the Cabinet. Abdul Qaiyum Khan, Minister for the interior giving explanation in support of the action of the Speaker said that the Cabinet could invite any person to attend its meeting but he altogether ignored that it lowered the status of the National Assembly in front of the Cabinet. Another minister Sheikh Muhammad Rashid tried to clarify that the Prime Minister had to discuss the schedule of the Budget session and had invited the Speaker to attend the meeting. (NAD, 1974, June 24)

The observation of the Speaker that he "was 'summoned' about the legislative business before the Assembly as to how long the Budget session will continue and what was the programme, how much the time will the present session consume and whether the members would like to have some recess," again expressed that the Parliament's legislative decisions were made in the meetings of the Cabinet. (NAD, 1974, June 24) The Speaker further informed that, from the day he had been elected as Speaker, he had not attended any party meeting or any public meeting or held any Press Conference. (NAD, 1974, June 24) This was answer of allegation that the Speaker had become partial by attending the meeting of the Cabinet but neither Qasuri stressed not the Speaker 
mentioned that the honour of the Parliament was lowered at the very moment when the Speaker was 'summoned' to attend the meeting of Cabinet.

This encroachment of the Cabinet over the position of the custodian of the National Assembly took place in the days when Ahmad Raza Kasuri, an active member of the National Assembly, made a statement during his visit to England to the effect that the Assembly had no legal status and as such he had no respect for the House. The Speaker did not let the issue be discussed in the House and called Qasuri in his chamber to 'explain certain matters' which were 'for the benefit of the House' and for 'the benefit of the democracy'. (NAD, 1974, June 24)

In the Parliamentary form of government ministers are supposed to be answerable to the Parliament and for this purpose their presence in the sessions of the Parliament is considered obligatory. But often the concerned ministers did not feel it suitable to attend the sessions of the NA regularly. Some of the instances of such attitude are that on $28^{\text {th }}$ November, 1975, Begum Nasim Jahan mentioned that the Minister-in-charge was not present in Senate during the debate on a bill. The Chairman pointed out that the law Minister, a Minister of State and the Parliamentary Secretaries were sitting in the House. The Chairman remarked that in a democratic Government that Cabinet was collectively responsible. (NAD, 1975 November 28)

In the meeting of NA held on the 28th August, 1972, a Member sought leave to move a privilege motion alleging a breach of the privilege of the Members of NA said to have been committee by Iftikhar Ahmad Tari, a Provincial Minister in the Punjab government by threatening the over with dire consequences in case he raised a point of privilege against the Government of the Punjab as was done by him earlier in a meeting of the NA when it was sitting a Constitution-making body. The mover added that what the Minister said was a direct threat to the freedom of the elected representatives in the Opposition. He produced copies of the newspapers in which the said remarks of Iftikhar Ahmad Tari were published. The Minister for Education and provincial Co-ordinations raised a point of order objecting to the admissibility of the privilege motion on the ground that the reference was to an incident which occurred when the national Assembly was sitting as a Constitution-making body. He, therefore, argued that under the rules this matter should be raised by the member when the Assembly sits as a Constitution-making body. (NAD, 1972, August 28)

It was also contended that the speech of the Minister of the Punjab violated the privilege of a member of the National Assembly. The matter was decided to be discussed in the House. There was motion for referring the matter to the privileges Committee; but, after getting the sense of the House, the Speaker announced that the matter is referred to the privileges Committee which will make its report to the house by the 5th of September, 1972. (NAD, 1972, August 28)

\section{Conclusion}

In the concluding remarks of this discussion it is suitable to contend that parliament remained the minimal influential in contrast to the bureaucracy and cabinet, the institutions which themselves treading the lines given by the Chief Executive of the country. The Constituent Assemblies from 1947 to 1956 and National Assemblies during Ayub era worked as weaker institutions before other institutions of the state like bureaucracy and cabinet which were relied upon or dictated by the individuals who were either individual civil authority or the military dictator. During Bhutto period there was directly elected parliament but except in the field of constitution making the dominating role of parliament in contrast to other stronger institutions remained minimal.

\section{References}

Ahmad, G. (1962) Changes in the Administrative Organization of GOP since 1953. In Inayatullah (Ed.), Bureaucracy \& Development in Pakistan. Peshawar: Pakistan Academy for Rural Development.

Ahmad, M. (1959). Government and Politics in Pakistan. Karachi: Pakistan Publishing House.

Alavi, H. (1988). Politics of Ethnicity in India and Pakistan. In H. Alavi, \& J. Harriss (Eds.), Sociology of Developing Societies South Asia. Hampshire: Macmillan.

Ayoob, M. (1972). The Military in Pakistan's Political Development. In S. P. Varma, \& V. Narain (Eds.), Pakistan Political System in Crisis. Jaipur: South Asia Studies Centre, University of Rajasthan.

Bhuiyan, M. A. W. (1982). Emergence of Bangladesh and Role of Awami League. New Delhi: Vikas Publishing House.

Brief. (1976). Visit of Margaret Thatcher, Leader of the Opposition, to India and Pakistan, FCO 37/1787. The National Archives London.

British Ambassador Islamabad. (1973). To Secretary of State FCO, Diplomatic Report No. 392/73, 16 August, FCO 37/1334. The National Archives (TNA) London. 
CAP. (1955, November 9). Constituent Assembly Pakistan. Debates, 1, 2777-2778

Chowdhury, M. (1988). Pakistan - Its Politics and Bureaucracy. New Delhi: Associated Publishing House.

Goodnow, F. (1964). The Civil Service of Pakistan. New Haven: Yale University Press.

Hamid, S. S. (1993). Early Years of Pakistan. Lahore: Ferozsons (Pvt.) Ltd.

Hasan, M. (2000). The Mirage of Power. Karachi: Oxford University Press.

Islam, R. (1987). The Bangladeshi Liberation Movement. Dhaka: The University Press Limited.

Kaushik, S. N. (1985). Pakistan under Bhutto's Leadership. New Delhi: Uppal Publishing House.

Kennedy, C. H. (1987). Bureaucracy in Pakistan. Karachi: Oxford University Press.

Mazari, S. K. (2001). A Journey to Disillusionment. Karachi: Oxford University Press.

Porte, R. L. (1976). Power and Privilege: Influence and Decision-Making in Pakistan. New Delhi: Vikas.

Sayeed, K. B. (1958, June). The Political Role of Pakistan's Civil Service. Pacific Affairs, 31, 131-146. http://dx.doi.org/10.2307/3035208

Shafqat, S. (2002). Democracy and Political Transformation in Pakistan. In S. Mumtaz, J. L. Racine, \& I. A. Ali (Eds.), Pakistan the Contours of State and Society (pp. 209-235). Karachi: Oxford University Press.

Siddiqa, A. (2007). Military Inc. inside Pakistan's Military Economy. Karachi: Oxford University Press.

Waseem, M. (2006). Democratization in Pakistan, a Study of the 2002 Election. Karachi: Oxford University Press.

Yusuf, H. (1980). The Return of the Politicians. Lahore: Afrasia Publications.

\section{Notes}

Note 1. National Assembly Debates. (1972). August, 28.

Note 2. National Assembly Debates. (1974). vol. 4, No. 21, June 24.

Note 3. National Assembly Debates. (1975). vol. 8, No.22, November 28.

Note 4. National Assembly Debates. (1974). vol. 6, No.15, December, 17.

Note 5. Senate Debates, 1976, February 27.

\section{Copyrights}

Copyright for this article is retained by the author(s), with first publication rights granted to the journal.

This is an open-access article distributed under the terms and conditions of the Creative Commons Attribution license (http://creativecommons.org/licenses/by/3.0/). 